\title{
AZ INFOKOMMUNIKÁCIÓS ÁGAZATOK SZEREPE ÉS SÚLYA A MAGYAR VÁROSHÁLÓZATBAN
}

\author{
(The Role and Weight of Information and Communication \\ Sectors in the Hungarian City Network)
}

\section{DÖRY TIBOR-PONÁCZ GYÖRGY MÁRK}

\begin{abstract}
Kulcsszavak:
információs és kommunikációs technológiák médiagazdaság tudastársadalom innovációk diffúzioja

Az információs korban a kommunikációs ismeretanyag megszerzése messze túllép a nemzeti határokon. E folyamatot erôsíti, hogy a telekommunikációs hardver költsége jelentósen csökkent az elmúlt években, így ennek elönyeiböl a lakosság szélesebb rétegei is részesülhetnek. A társadalmilag méltányos és a terïletileg kiegyenlített információs társadalom épitésének feladata azonban többet jelent a technikai információs és kommunikációs technológiai (IKT) kapacitások kiépitésénél. A tanulmány ennek jegyében az infokommunikációs szektorhoz és a médiagazdasághoz tartozó cégek oldaláról mutatja be kutatási tapasztalatainkat. A statisztikai adatok megyei és megyei jogú város szintũ elemzése alapjan nyert tapasztalataink megerôsítették azt a kiinduló hipotézisünket, miszerint e szektorok magas fokú koncentrációja figyelhe tỏ meg Budapesten, ahol is az IKT-vállalkozások több mint fele, a médiagazdaság vállalkozásainak közel kétharmada koncentrálódik..
\end{abstract}

\section{Bevezetés}

A 21. században, az informatika századában új típusú kihívásokkal szembesülnek a nemzetállamok, amelyek a korábbitól jelentősen különböző állami hozzáállást, a területi különbségek kezelésekor új módszerek alkalmazását követelik meg. Az információs társadalom fejlödésének legfőbb akadályát az jelenti, ha a lakosság, a közszféra, illetve a vállalkozások nem ismerik fel az új típusú kihívásokat, valamint nem megfelelőek az infokommunikációs ismereteik. Ebből következően fokozott mértékủ állami szerepvállalásra van szükség, melynek segítségével ösztönözni lehet a lakosság, a közintézmények és a vállalkozások körében az információs- és kommunikációs technológiák (IKT) hatékony használatát és ezzel összefüggésben e szereplök képessé tételét az IKT-eszközök, megoldások igénybevételére. Amikor ugyanis a gazdasági élénkülésröl vagy a fenntartható fejlödésról beszélünk, akkor ez egyúttal a világon meglévő emberi tudásanyag rendkívül gyors mértékủ és sebességủ bövülését is jelenti. A Világbank elemzését ${ }^{1}$ részletesen bemutató hazai tanulmány ( $K S H$ 2000) megállapítása szerint a szegény országok vagy szegény népek és gazdagok közötti legfontosabb eltérés nemcsak a tỏke állományában mutatkozik meg, hanem a tudásállományban is. A tudásállomány ugyanis csak igen költségesen fejleszthetö, és így elsősorban az iparilag fejlett országokra jellemző annak gyors bővülése, a tudás terjedése. 
A tudás modern közgazdasági felfogásáról annyit feltétlenül el kell mondani, hogy az a tőkéhez hasonlóan akkumulálható, összegyűjithetỏ termelési tényezö. Viszont a tudás el is felejthető, mert ha nem használják, akkor egyszerüen elveszik. A tudásnak térbeli és időbeli dimenziója is van, ami az idő múlásával átdiffundál(hat) a régióhatárokon. A tudás terjedése során át is alakul: az eredeti tudás egyes részei elveszhetnek, mások új tartalommal gazdagíthatják azt.

Dohse (1998) a tudás négy komponensét különbözteti meg:

- a tényszerú tudást ("know what"), ami magát az információt takarja;

- az összefüggések ismeretét ("know why");

- a tudás fogalom személyhez kötött dimenzióját ("know who");

- végül pedig a közismertebb "know how" a tudás gyakorlati megvalósí-tásának képességét mutatja.

Regionális gazdaságtani szempontok szerint az ismertetett tudás összetevők különféleképpen ítélhetők meg: a "know what" és a "know why" elvileg standardizálhatók, kódolhatók és nagyobb távolságokba is transzferálhatók. Ezekben az esetekben a térbeli közelség nem játszik különösebb szerepet a tudásátadás folyamatában. Ezzel szemben a "know who" és a "know how" csak nehezen és számos megszorítás mellett transzferálható, hiszen ezek sok esetben nehezen kódolhatók, az adott helyzettöl függök.

A tudás szerepet játszik a különbözó térségek fejlödésében, de Polányi (1958) szerint a tudás bizonyos típusai nagyobb távolságokra csak nehezen transzferálhatók, mivel a nyelvi és kulturális akadályok kódolását, hủ visszaadását nem teszik lehetővé. Ez különösen arra a tudásra igaz, amely relative új, létrehozásának korai fázisában van még, és inkább csak az, „ötlet" szintjén mozog. Az utóbbi két tudásformára használja az angol a "tacit knowledge", a német pedig a "gebundenes Wissen" fogalmat, ami magyarul rejtett vagy hallgatólagos tudásra fordítható. Ebben az esetben a térbeli közelségnek, a szemtỏl szembe ("face-to-face") kapcsolatoknak elsörangú jelentösége van. Emellett további okok is megemlíthetök a tudás térbeli egyenlőtlen megoszlásának indoklására:

- A tudás gyakran kontextusfüggö, azaz csak egy bizonyos helyen és időpontban értékes, más térbeli, időbeli és szociális környezetben nem hasznosítható.

- A tudás birtokosai közötti informális kommunikáció, a térbeli közelség ugyanis lerövidíti az információ útját, a hozzájutás idejét, ami termékenyítỏleg hat a tudás cseréjére is, sőt mindemellett csökkenti a tranzakciós költségeket is.

- Az új tudás gyakran interaktív módon vegyes vállalatok vagy innovációs hálózatok keretei közỏtt jön létre. A vállalati stratégiai szövetségek és vegyes vállalatok (egy konszernhez, kủilföldi céghez tartozó leányvállalatok) esetén a térbeli távolság ellenére, a megalapozott személyes kapcsolatok miatt rendkívuil gyorssá és hatékonnyá válik az információáramlás.

- Egyes iparágak területi koncentrációja is ösztönzỏleg hat erre a folyamatra, de mindez csak akkor müködik, ha a megismert tudást ténylegesen is alkalmazzák ("learning by doing"). 
Az elmondottakból következik, hogy az új technikai vagy közgazdaságilag fontosnak tekinthetö tudás a térben korlátozottan áll rendelkezésre még az internet korában is. Azonban a tudás terjedése nem áll meg a régió határoknál. Ebböl következöen a tudást olyan lokális, mindenki számára elérhetö jószágnak tekinthetjük, amelynek dinamikus továbbgyürüzỏ („spillover-hatásai”) vannak. A regionális fejlödésre nézve pedig ez azt jelenti, hogy az új technikai tudás terjedésének meghatározó szerepe van. A régiók gazdasági fejlödését elősegítő politikáknak pedig azt kell figyelembe venni, hogy az új technikai tudás pozitiv extern hatásai általában csak annak a régiónak, illetve kistérségnek a gazdaságában érvényesülnek-e, ahol a tudást létrehozták (Varga 1998).

Többek között e felismerésnek köszönhetöen kapott különös figyelmet és élvez egyértelmủ prioritást az Európai Unió regionális politikájában és a közösségi szintủ kutatás-fejlesztési keretprogramokban az információs társadalom projektek támogatása. Az uniós tagállamok a Strukturális Alapok forrásait is fel kívánják használni az eEurope akcióterv megvalósítására Európa különbözö régióiban, csökkentendő a régiók közötti jelentős infokommunikációs különbségeket, a „digitális megosztottságot”.

A tanulmány elsődleges célja, hogy bemutassa, milyen térszerkezetben jelenik meg az infokommunikációs szektor és a médiagazdaság Magyarországon. Vizsgálódásainkat városi szinten végeztük el, hiszen az IKT-technológiák meglehetösen magas koncentrációt mutatnak a fejlett centrumokban, a nagyvárosokban, vagyis a telepuiléshierarchia magasabb szintjein történik a valódi alkalmazás. Ennek megfelelően az intézményi-szereplöi bázis is elsősorban a városokban fejlett. A téma feldolgozása különösen aktuális, hiszen a tudomány fejlődése, a tudásmennyiség növekedése felgyorsult, így a tudásgazdaság ágazataiban néhány év elteltével az azonos területen végzett megismételt kutatás újdonságként könyvelhető el. A magyar szakirodalomban kevés a kifejezetten az információs társadalom és gazdaság jellemzőinek mérésére vállalkozó munka ${ }^{2}$, és ezek sem fordítanak kellö frgyelmet a területi folyamatok komplex megközelítésére ${ }^{3}$. Jelen tanulmány egy kezdeményezésnek tekinthetö, amely reflektorfénybe helyezi a megyék és megyei jogú városok információgazdaságának egyes jellemzőit.

Magyarország gazdaságának felzárkózása az Európai Unió fejlettségi szintjére erősen függ attól, hogy sikerül-e áthidalni a tudományos és technológiai rést, ezért föleg a magyar tudásgazdaság növekedése fogja eldönteni, hogy milyen helyet foglalhatunk el a nemzetközi munkamegosztásban. A tudomány-és technológiapolitika, illetve az innovációk regionális szintủ elemzése során is kiderült, hogy ezek a tényezők katalizátorszerepet tölthetnek be az új iparágak létrejöttében (DöryRechnitzer 2000). Az információs és kommunikációs technológiák esetében hasonló fontosságú lehet a térbeli elhelyezkedés, a telephelyválasztás motívumai, a növekedés lehetőségeinek területi eltérése, és nem utolsósorban ezen kulcsfontosságú szektorok területi egyenlötlenségeinek társadalmi hatása.

Az információs és kommunikációs technológiai szektor (IKT) és a médiagazdaság vizsgálata során mindvégig szem előtt tartottuk, hogy ezek a gazdasági szegmensek, mint a tudásipar reprezentánsai, kettős beágyazottságúak: egyrészt a technológiai adottságok által, másrészt a társadalmi befogadás által meghatározottak. A felsőok- 
tatás és a kutatás helyzete, a humán infrastruktúra jellemzői determinálják az információs technológiák fejlődési lehetőségeit, ami visszahat az érintkezéskultúrára, a jólét szintjére és a tudomány müvelésének mikéntjére.

A hazai információs társadalom megfelelő kialakulásához szükséges, hogy a társadalom tömegesen befogadja az informatikai eszköztárat (Glatz 2000). Az IKT szektor egyes szegmenseire (mobilkommunikáció, személyi számítógépek piaca) jellemzö erös gazdasági verseny sokat javított az új technológiák használatának elterjedtségén, és az oktatás területén az elmúlt években végrehajtott infrastrukturális fejlesztések is éreztetik a hatásukat. A kormány aktív szerepvállalása továbbra is létfontosságú: a Nemzeti Információs Társadalom Stratégia (2001) beavatkozási területeinek diverzitása is jelzi, hogy milyen komplex rendszerben érvényesülnek a tudástársadalom hatásmechanizmusai.

\section{Elméleti alapvetés, a kutatás korlátjai, hipotézisek}

Az információs társadalom gazdasági alrendszerét az IKT szektor és a médiagazdaság képezi le: itt történik meg az információs javak tömeges termelése, felhalmozása, kereskedelme, és az elektronikus információtartalmak megjelenítése, közvetítése. Ezen szektorok tevékenysége a gazdaság egészére átformáló hatást gyakorol, hiszen amelyik cég elmarad az új technológiák befogadásával, vagy az információs szolgáltatásokat nem veszi igénybe, komoly versenyhátrányba kerül. A tudásintenzív termékek piaca ezért egyre bövül, az erre specializálódó piaci stratégia versenyképesebbé teszi az adott vállalatot, illetve a szolgáltatási szektor számára elóállított termékek esetében csökkenti a konjunktúrától való függőséget. A gazdálkodói szemlélet és racionalitás értelmében tehát az IKT szektor és a médiagazdaság termékei és szolgáltatásai növekvö piaccal számolhatnak.

Az IKT szektorba és a médiagazdaságba való tartozás kritériumait „Az információs és kommunikációs technológiai szektor Magyarországon" (KSH 2001) kiadványból vettük át. Ezek alapján az IKT szektort tovább bontottuk feldolgozóipari tevékenységre, termékhez kapcsolódó IKT szolgáltatásra és termékhez nem kapcsolódó IKT szolgáltatásra. A cégek besorolása az ágazatokba a fő tevékenységük szerint, a TEÁOR '98 alapján történt, a Cég-Kód-Tár (KSH 2001) CD-adatbázis felhasználásával (1. táblázat).

Feldolgozóipari tevékenységet végzők közé az információ feldolgozását, megjelenítését és a kommunikációt szolgáló termékek, továbbá a fizikai folyamatok elektronikus adatfeldolgozás segítségével történő érzékelését, mérését, regisztrálását, irányítását szolgáló termékek, illetve az ezekbe beépủlỏ alkatrészeket gyártó vállalkozások sorolhatók. A szolgáltatások esetében az elektronikus úton megvalósuló információ-feldolgozás, -tárolás, kommunikációs képesség biztosítása, illetve az ezekhez tartozó termékek kereskedelme, kölcsönzése volt a besorolás szempontja. A médiagazdaságba a különböző képi és hangos információhordozók elöállítása, a sajtó és nyomtatott termékek eloóllítása, az elöbbiek sokszorosítása, a postai és hirdetési tevékenység, a film- és videogyártás, -kölcsönzés, a rádió-és televízió-szolgáltatás tartoznak. 


\section{TÁBLÁZAT}

A szakágazatok besorolása az IKT szektorba és a médiagazdaságba a TEÁOR '98 alapján (The Classification of Subbranches in ICT Sector and Media Economy by TEÁOR '98)

\section{Feldolgozóipar}

\begin{tabular}{ll}
\hline 3001 & Irodagépgyártás \\
3002 & Számítógépgyártás \\
3130 & Szigetelt vezeték és kábel gyártása \\
3210 & Elektronikus alkatrész gyártása \\
3220 & Ipari híradástechnikai termék gyártása \\
3230 & Híradástechnikai fogyasztási cikk gyártása \\
3320 & Mérómúszer gyártása \\
3330 & Ipari folyamatirányító rendszer gyártása \\
\hline \multicolumn{2}{l}{ Termékhez kapcsolódó IKT szolgáltatás } \\
\hline 5143 & Elektronikus háztartási cikk nagykereskedelme \\
5164 & Irodagép, -berendezés nagykereskedelme \\
7133 & Irodagép, számítógép kölcsönzése \\
\hline \multicolumn{2}{c}{ Termékhez nem kapcsolódó IKT szolgáltatás } \\
\hline 6240 & Távközlés \\
7210 & Hardver-szaktanácsadás \\
7220 & Szoftverkészítés, -szaktanácsadás \\
7230 & Adatfeldolgozás \\
7240 & Adatbanki tevékenység \\
7260 & Számítástechnikai tevékenység \\
\hline & $\quad$ Médiagazdaság \\
\hline & 221x, 222x, 223x, 64lx, 744x, 921x, 922x \\
\hline
\end{tabular}

Forrás: KSH 2001.

A vizsgálatok során a Cég-Kód-Tár ( $K S H$ 2001) adatbázisából azoknak a vállalkozásoknak az adatait használtuk fel, amelyek fö tevékenységi körük alapján, a TEÁOR ' 98 besorolási rendje szerint a korábban lehatárolt IKT szektorba vagy a médiagazdaságba sorolhatók, és valamely magyar városban székhellyel rendelkeznek. Értelemszerüen kimaradtak a városi ranggal nem rendelkező települések vállalkozásai, de figyelembe véve, hogy ezeknek az IKT szektorban és médiagazdaságban betöltött szerepe csekély, hiányuk nem torzítja jelentősen a vizsgálat eredményeit, a megyénkénti összehasonlítások esetében pedig még kevésbé zavaró ez a körülmény. Az IKT szektorbeli vagy médiagazdaságba tartozó cégek darabszámát más jellemzö értékekkel is összevettük, ezek közül a városok népessége 1999-es KSH-adat. A vizsgált vállalkozások dolgozóinak létszáma, éves árbevétele csak bizonyos (elég tág) intervallumként volt megadva a Cég-Kód-Tárban, és az intervallumonkénti eloszlás feltételezhetỏen nem egyenletes, ezért a vizsgálati szempontok között ezeket az adatokat nem szerepeltettük. Mindez korlátozza a kapott 
eredmények érvényességét, de még így is jó közelítését adja a valós helyzetnek. Módszertanilag a cégek fö tevékenység szerinti csoportosítása vélhetően elfogadható, de hozzá kell tenni, hogy ezekben az ágazatokban magas fokú a cégek flexibilitása, változásokra való fogékonysága, és a kisvállalkozások esetében jellemző a több lábon állás is.

A tanulmány elsó hipotézise szerint a IKT szektor és médiagazdaság területi és regionális koncentrációja nagymértékü: feltételezhető, hogy Budapesten összpontosul az ezen körbe tartozó cégeknek akár ötven százaléka. Erre utal, hogy a BÉT-re bevezetett távközlési és informatikai részvénytársaságok (Antenna Hungária, MATÁV, Synergon, Graphisoft) központjai Budapesten vagy Pest megyében találhatók. A mobilkommunikációs cégek (Westel 900 Rt., Westel Rádiótelefon Kft., Pannon GSM Rt., Vodafone Távközlési Bt.) székhelye szintén a fővárosban található. A vezetô magyar IKT-cégek is a nagy centrumokban telepedtek meg (2. táblázat). Feltünő, hogy az árbevételi kategória alapján rangsorolt első 55 cég 70,9 százalékának Budapesten található a székhelye.

\section{TÁBLÁZAT}

Az elsö húsz 4 milliárd forint feletti forgalmú IKT-cég Magyarországon (The First 20 ICT Firms in Hungary with Return More Than 4 Billions HUF)

\begin{tabular}{|c|c|c|c|}
\hline Cégnév & Székhely & Cégnév & Székhely \\
\hline MATÁV Rt. & Budapest & Pannon GSM Távközlési Rt. & Budaörs \\
\hline Flextronics Kft. & $\mathrm{Tab}$ & Ericsson Magyarország Kft. & Budapest \\
\hline Videoton Holding Rt. & Székesfehérvár & SONY Hungaria Kft. & Budapest \\
\hline IBM Storage Products Kft. & Székesfehérvár & Matávcom Kft. & Budapest \\
\hline AFL Hungary Kft. & Mór & $\begin{array}{l}\text { Clarion Hungary Elektronikai } \\
\text { Kft. }\end{array}$ & Nagykáta \\
\hline Delphi Packard Kft. & Szombathely & TDK Eleketronika Kft. & Rétság \\
\hline Antenna Hungária Rt. & Budapest & Samsung Electronics Magyar Rt. & Budapest \\
\hline $\begin{array}{l}\text { Westel Mobil Távközlési } \\
\text { Rt. }\end{array}$ & Budapest & MKM Magyar Kábel Múvek Rt. & Budapest \\
\hline Zollner Elektronik Kft. & Vác & Ikarus Alba Kft. & Székesfehérvár \\
\hline SCI Magyarország Kft. & Tatabánya & Emitel Távközlési Rt. & Szeged \\
\hline
\end{tabular}

Forrás: Cég-Kód-Tár alapján saját számítás (2001).

A második hipotézisünk az volt, hogy az IKT szektor és a médiagazdaság erös kölcsönhatásban áll a helyi gazdaság többi szereplőjével, ezért jelenléte (vagy hiánya) befolyásolja a városok versenyképességét. Lengyel Imre és Rechnitzer János (2000) A városok versenyképességéról címủ tanulmánya a magyar városhálózat versenyképességére ható tényezỏket vizsgálta, és rangsorba rendezte a megyei jogú városokat. Az elemzés kimutatta, hogy azok a városok tudták stabilizálni a helyzetüket, amelyek nagyobb népességgel, kiterjedt vonzáskörzettel, több szintű intézményrendszerrel és jobb jövedelemtermeló képességgel rendelkeztek. Arra keresünk választ, hogy az IKT szektor és a médiagazdaság jellemzöi mennyire illeszkednek (ha illeszkednek) a városok elöbb hivatkozott versenyképességi mutatóihoz. 


\section{Az IKT szektor és a médiagazdaság súlya a magyar gazdaságban}

Az infokommunikációs szektor a teljes nemzetgazdasági létszám 5,1 százalékát foglalkoztatta 1998-ban, az IKT szektor a müködő vállalkozások 3 százalékát tette ki (KSH 2001). Jelen felmérés szerint az összes gazdasági tevékenységet folytató cég számához viszonyítva az IKT szektor 4,19 százalékkal, a médiagazdaság további 3,8 százalékkal részesedik, együtt 7,98 százalékot tesznek ki (3. táblázat).

\section{TÁBLÁZAT}

Az IKT szektor és a médiagazdaság aránya a gazdasági tevékenységet folytató szervezetek körében, 2001

(The Rate of ICT Sector and Media Economy in All Economic Organisations, 200I)

\begin{tabular}{lrr}
\hline \multicolumn{1}{c}{ Tevékenységi kategória } & Cégek száma & Aránya (\%) \\
\hline Feldolgozóipar & 1806 & 0,46 \\
Termékhez kapcsolódó IKT szolgáltatás & 1749 & 0,45 \\
Termékhez nem kapcsolódó IKT szolgáltatás & 12856 & 3,28 \\
Médiagazdaság & 14896 & 3,80 \\
Gazdasági tevékenységet folytató szervezetek összesen & $392 I 27$ & 100,00 \\
\hline
\end{tabular}

Forrás: Cég-Kód-Tár alapján saját számítás.

Folytatódni látszik az a dinamikus fejlődés, amit az IKT szektor mutatott az elmúlt években: az ágazat nettó árbevétele 3,2-szeresére növekedett 1995 és 1998 között (4. táblázat). A szektor növekedésének fö forrása az exportra termelés, amely az IKT feldolgozóiparban a négy év alatt megtizenháromszorozódott, az egész szektort tekintve pedig közel megnyolcszorozódott.

\section{TÁBLÁZAT}

Az IKT szektor szakágazatainak nettó árbevétele, folyó áron, 1995-1998

(Net Return of Subbranches of ICT Sector in Current Price, 1995-1998)

\begin{tabular}{|c|c|c|c|c|c|}
\hline \multirow{2}{*}{ Szakágazat } & \multicolumn{4}{|c|}{ Nettó árbevétel (millió Ft) } & \multirow{2}{*}{$995=100 \%$} \\
\hline & 1995 & 1996 & 1997 & 1998 & \\
\hline IK & 202888 & 374163 & 8037201 & 1087355 & $535,9 \%$ \\
\hline $\begin{array}{l}\text { IKT termékhez kapcsolódó } \\
\text { szolgáltatás }\end{array}$ & 183097 & 222224 & 268986 & 285895 & $56,1 \%$ \\
\hline $\begin{array}{l}\text { Termékhez nem kapcsolódó } \\
\text { IKT szolgáltatás }\end{array}$ & 265258 & 387146 & 536401 & 740567 & $279,2 \%$ \\
\hline IKT szektor c & 651242 & 983533 & 6091072 & 2113816 & $324,6 \%$ \\
\hline $\begin{array}{l}\text { Összes kettős könyvvitelt } \\
\text { vezetô vállalkozás }\end{array}$ & 11070210 & $862-2$ & 82442302 & 13808 & $205,4 \%$ \\
\hline
\end{tabular}

Forrás: KSH 2001. 


\section{Az ország terïleti polarizáltsága, Budapest vezetö szerepe}

A magyar IKT szektor és médiagazdaság térbeli szerkezete erősen polarizált, Budapesten összpontosul az IKT szektor cégeinek 56\%-a, a médiagazdaság 63\%-a. Ha hozzávesszük Pest megyét, akkor az értékek 68,4\%-ra, illetve 73,9\%-ra módosulnak. A Központi régió lakosságszámához, gazdasági kibocsátásához képest is aránytalanul nagy mértékủ részesedéssel bír az ezen szakágazatokban tevékenykedö cégek számából (5. táblázat).

\section{TÁBLÁZAT}

Az IKT szektor és a médiagazdaság cégeinek megyénkénti megoszlása (ICT Sector and Media Economy)

\begin{tabular}{|c|c|c|c|c|c|c|c|c|}
\hline & Megye & (A) & (B) & (C) & (D) & (E) & (F) & (G) \\
\hline 1 & Budapest & 887 & 939 & 7466 & 9292 & $1132,41 \%$ & 9472 & $1271,75 \%$ \\
\hline 2 & Baranya & 46 & 41 & 321 & 408 & $49,72 \%$ & 372 & $49,95 \%$ \\
\hline 3 & Bács-Kiskun & 60 & 51 & 294 & 405 & $49,36 \%$ & 337 & $45,25 \%$ \\
\hline 4 & Békés & 20 & 26 & 114 & 160 & $19,50 \%$ & 183 & $24,57 \%$ \\
\hline 5 & Borsod-A-Z. & 56 & 42 & 362 & 460 & $56,06 \%$ & 338 & $45,38 \%$ \\
\hline 6 & Csongrád & 37 & 89 & 320 & 446 & $54,35 \%$ & 285 & $38,27 \%$ \\
\hline 7 & Fejér & 79 & 36 & 345 & 460 & $56,06 \%$ & 279 & $37,46 \%$ \\
\hline 8 & Györ-M-S. & 49 & 68 & 281 & 398 & $48,50 \%$ & 276 & $37,06 \%$ \\
\hline 9 & Hajdú-Bihar & 34 & 60 & 337 & 431 & $52,53 \%$ & 300 & $40,28 \%$ \\
\hline 10 & Heves & 37 & 16 & 147 & 200 & $24,37 \%$ & 138 & $18,53 \%$ \\
\hline 11 & $\begin{array}{l}\text { Komárom- } \\
\text { Esztergom }\end{array}$ & 43 & 28 & 213 & 284 & $34,61 \%$ & 176 & $23,63 \%$ \\
\hline 12 & Nógrád & 20 & 6 & 75 & 101 & $12,31 \%$ & 105 & $14,10 \%$ \\
\hline 13 & Pest & 243 & 191 & 1500 & 1934 & $235,70 \%$ & 1532 & $205,69 \%$ \\
\hline 14 & Somogy & 22 & 28 & 153 & 203 & $24,74 \%$ & 164 & $22,02 \%$ \\
\hline 15 & Szaboles-Sz.-B. & 26 & 38 & 211 & 275 & $33,51 \%$ & 180 & $24,17 \%$ \\
\hline 16 & Jász-N-Sz. & 44 & 22 & 162 & 228 & $27,79 \%$ & 177 & $23,76 \%$ \\
\hline 17 & Tolna & 18 & 14 & 127 & 159 & $19,38 \%$ & 92 & $12,35 \%$ \\
\hline 18 & Vas & 26 & 22 & 134 & 182 & $22,18 \%$ & 133 & $17,86 \%$ \\
\hline 19 & Veszprém & 33 & 14 & 157 & 204 & $24,86 \%$ & 194 & $26,05 \%$ \\
\hline \multirow[t]{3}{*}{20} & Zala & 26 & 18 & 137 & 181 & $22,06 \%$ & 163 & $21,89 \%$ \\
\hline & Összesen & 1806 & 1749 & 12856 & 16411 & & 14896 & \\
\hline & Átlag & 90,3 & 87,45 & 642,8 & 820,55 & $100,00 \%$ & 744,8 & $100,00 \%$ \\
\hline
\end{tabular}

Megjegyzés: (A) feldolgozóipar; (B) IKT termékhez kapcsolódó szolgáltatás; (C) Termékhez nem kapcsolódó IKT szolgáltatás; (D) IKT szektor összesen; (E) IKT szektor a megyék átlagának százalékában; (F) Médiagazdaság; (G) Médiagazdaság a megyék átlagának százalékában

Forrás: Cég-Kód-Tár alapján saját számítás. 
A táblázatból kitünik, hogy az IKT szektor és a médiagazdaság jelenléte vagy hiánya többnyire együttesen fordul elö. A megyéket a két ágazatban mủködő cégek darabszáma alapján sorrendbe állítva azt tapasztaljuk, hogy a két ágazat szerinti sorrendiség nagyfokú egyezést mutat. Az ordinális változók kapcsolatát különféle módszerekkel vizsgálhatjuk, ezek közül most a Kendall-féle konkordancia mutatót ${ }^{4}$ választottuk, amire $\mathrm{W}=0,95$ adódott. Ez a mutató azért is hasznos, mert a késỏbbi vizsgálatoknál lehetséges újabb ismérvek szerinti sorrendek egyezöségének vizsgálatára is alkalmas. A mutató nagyon magas értéke bizonyítja, hogy a két ágazat együtt, egymás közelében települ meg, azaz a városok nyújtotta társadalmigazdasági keretfeltételek milyensége, a miliő azonos irányban (söt azonos mértékben) befolyásolja a két ágazat cégeinek elöfordulási gyakoriságát.

Schönert és Willms (2000) a nẻmet nagyvárosokban jelen lévő médiaszektor elemzését bemutató tanulmányukban ún. lokalizációs koefficienst számoltak az egyes nagyvárosokra. A rendelkezésünkre álló adatbázis is lehetỏvé tette e mutató kiszámítását a magyar megyék tekintetében. A lokalizációs koefficiens kiszámításához két ismérv megadása szükséges területi bontásban, amelyek hányadosaiból területi egységenként egy-egy fajlagos mutatót kapunk. Ezeket a fajlagos mutatókat a teljes sokaságra jellemzó fajlagos mutatóhoz viszonyítva kapjuk a lokalizációs koefficiens adott területekre jellemző értékeit. A lokalizációs koefficiens azt mutatja meg, hogy az adott településre vagy területre jellemző érték (itt a 10 ezer lakosra jutó cégek száma) hányszorosan haladja meg az országos átlagot. Az alábbi két számítás esetében Budapest kiugró értéke miatt majdnem minden más megyére törtszámok adódnak. A lokalizációs koefficiens hasznos benchmarking eszköznek bizonyult, és lehetövé tette a megyék csoportosítását. A lokalizációs koefficiens a nagy népességủ megyékre nem ad automatikusan magasabb értéket, sokkal inkább az adott ágazat megyénkénti fejlettségét, a népességszámhoz viszonyított arányát tükrözi vissza, bár figyelembe kell venni, hogy elfedi a területen belüli megoszlás különbségeit. Budapest (és más megyék) esetében számolni kell azzal, hogy az országos hálózattal rendelkező (távközlési, adatkezelő stb.) cégek székhelye a fővárosban van, de más településeken is tevékenykednek, és alkalmaznak vidéki munkavállalókat. Jelen tanulmányban a cégek darabszámát használtuk fel a számításokhoz, ezért az előbbi tényezőt figyelmen kívül hagytuk.

Az IKT szektor megyei szintü lokalizációs koefficiensei (1. ábra) ugyancsak az ország Központi régiójának vezetô szerepét igazolják. A tízezer fơre jutó IKT cégek száma Budapesten 51,3, Pest megyében 18,7, így az országos átlagot (16,3) mindkettỏ meghaladja. Fejér, Csongrád, Baranya, Győr-Moson-Sopron és KomáromEsztergom megye az országos átlag 50-70 százalékát éri el, toyábbi tíz megye pedig 30-50 százalékát. Ez alatti értékkel Szabolcs-Szatmár, Nógrảd és Békés megye alkotja a leszakadók csoportját: Nógrádban összesen csak 101 darab IKT szektorba sorolt cég található. 
1. ÁBRA

Az IKT szektor megyei szintü lokalizációs koefficiensei

(County Level Localisation Coefficients of ICT Sector)

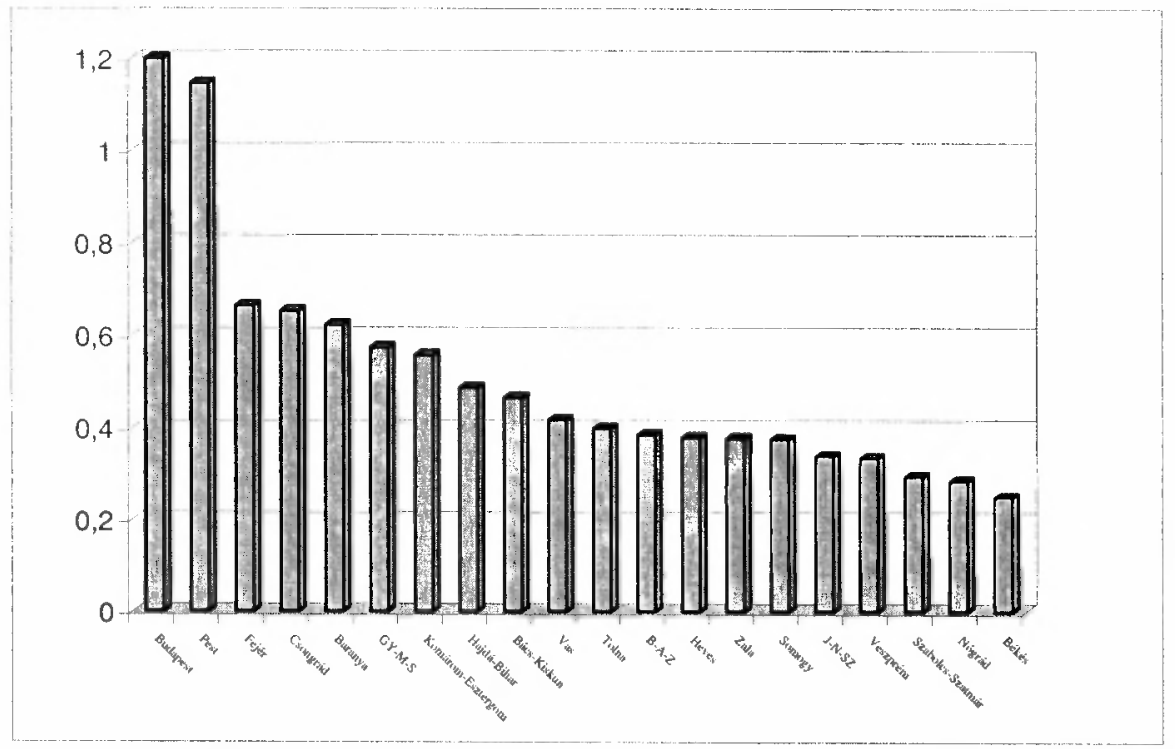

Forrás: Cég-Kód-Tár alapján saját számítás.

2. ÁBRA

A médiagazdaság megyei szintü lokalizációs koefficiensei

(County Level Localisation Coefficients of Media Economy)

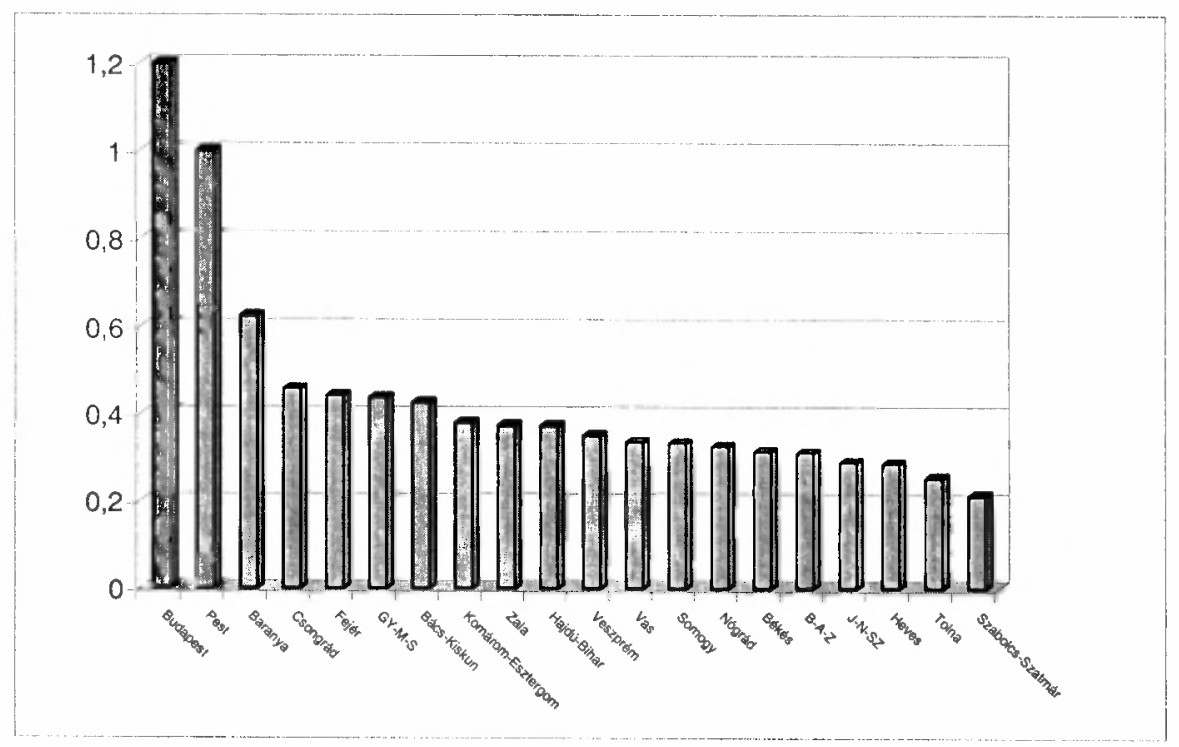

Forrás: Cég-Kód-Tár alapján saját számítás. 
A médiagazdaság lokalizációs koefficienseiből (2. ábra) az elözővel azonos tipizálás adódik, annyi különbséggel, hogy Budapest jelentősége még kiemelkedőbb, Tolna és Heves megye pedig a sereghajtók közé került. Meg kell jegyezni, hogy a németországi vizsgálat (Schönert-Willms 2000) is erös területi koncentrációt tárt fel, de ott a különböző ágazatokban más-más nagyváros játszik vezető szerepet, míg Magyarországon abszolút és relatív értéken egyaránt a fóváros az infokommunikációs szektor és a médiagazdaság centruma.

$\mathrm{Az}$ infokommunikációs szektor cégeinek ágazatok közötti megoszlása (6. táblázat) viszonylag stabil jellemző. A fejlettebb megyék értékei általában közelítenek az átlaghoz, tehát a jobb eredmények kiegyensúlyozott belső szerkezetet takarnak. Az egyetlen kivétel Budapest, ahol a termékhez nem kapcsolódó IKT szolgáltatás aránya országosan a legmagasabb. Ez nem véletlen: 1995 és 1998 között az IKT szektor szakágazataiban a szolgáltatások hozzáadott értéke 65,9 százalékról 74,1 százalékra nött a feldolgozóipar rovására ( $K S H$ 2001). Budapesten valószínúleg olyan szolgáltatások térnyerése zajlik, amelyeknél a hozzáadott érték egyre növekszik; ilyen például a hardver-szaktanácsadás, ahol ez négy év alatt nyolcszorosára emelkedett.

\section{TÁBLÁZAT}

Az IKT szektor belsö szerkezete; megoszlási viszonyszámokkal

(The Structure of ICT Sector with Percentage Frequency)

\begin{tabular}{|c|c|c|c|c|}
\hline & $\begin{array}{l}\text { IKT feldolgozó- } \\
\text { ipar }\end{array}$ & $\begin{array}{l}\text { IKT termékhez } \\
\text { kapcsolódó } \\
\text { szolgáltatás }\end{array}$ & $\begin{array}{l}\text { Termékhez nem } \\
\text { kapcsolódó IKT } \\
\text { szolgáltatás }\end{array}$ & Összesen \\
\hline & $11,00 \%$ & $10,66 \%$ & $78,34 \%$ & $100,00 \%$ \\
\hline Legkisebb érték & $\begin{array}{l}\text { Hajdú-Bihar } \\
(7,89 \%)\end{array}$ & $\begin{array}{l}\text { Nógrád } \\
(5,94 \%)\end{array}$ & $\begin{array}{c}\text { Jász-N-Sz. } \\
(71,05 \%)\end{array}$ & \\
\hline $\begin{array}{l}\text { Legnagyobb } \\
\text { érték }\end{array}$ & $\begin{array}{l}\text { Heves } \\
(18,50 \%)\end{array}$ & $\begin{array}{l}\text { Csongrád } \\
(19,96 \%)\end{array}$ & $\begin{array}{l}\text { Budapest } \\
(80,35 \%)\end{array}$ & \\
\hline
\end{tabular}

Forräs: Cég-Kód-Tár alapján saját számítás.

\section{Az IKT szektor és a médiagazdaság mint a városi versenyképesség tényezöi}

A regionális tudomány a versenyt komplex, térben is releváns viszonyrendszerként értelmezi, ezért beszélhetünk ma már városok, régiók, nemzetek, nemzetek feletti közösségek versenyéről. A területek funkciói, szolgáltatásai, aktorai által meghatározott kínálat és a globális szereplők (befektetők, vásárlók) kereslete együttesen alakítja ki a terület versenypozícióját (Palkovits 2000). Magyarországon a megyei jogú városok alkotnak olyan hálózatot, amely képes aktívan részt venni a globális versenyben. Feltételezésünk szerint az információs és kommunikációs termékek és szolgáltatások elérhetősége a hálózati gazdaságba való bekapcsolódás mértékének, így a hálózat tagjai közötti versenyben elfoglalt pozíciónak egy alkalmas indikátora. Ennek igazolására a megyei városok infokommunikációs jellemzőit összevetettük a Lengyel Imre és Rechnitzer János (2000) tanulmányában felállitott versenyképességi rangsorokkal. 
A megyei jogú városok IKT és médiagazdasághoz tartozó cégek száma alapján számított rangsora (7. táblázat) a városok több évtizedes hierarchiáját képezi le: Debrecen, Pécs, Szeged, Miskolc és Győr, mint megyei, később megyei jogú városok vezetik a sort, egyedül Székesfehérvár ékelödik be közéjük. A megyei jogú városok a megye népességéböl való részesedésüknél jóval nagyobb mértékben részesednek az IKT és a médiagazdaság cégeiből, átlagosan 2,89-szeresen. A koncentráció mértékében is jelentös eltérések vannak: a rangsort vezető városok, Györ kivételével, nagyon erösen koncentrálják a cégeket, négyszer-nyolcszor annyi céget tömörítenek az adott megyében, mint amennyit a népességük alapján várnánk. Amelyik megyében két megyei jogú város található, ott kevésbé tud érvényesülni a koncentrációs hatás, ezért a rangsorban legalább az egyik város hátrébb sorolódott (Dunaújváros, Sopron).

\section{TÁBLÁZAT}

A megyei jogú városok sorrendje az IKT és a médiagazdaság cégeinek száma alapján, 2001

(Order of County Rank Towns by the Number of Firms in ICT Sector and Media Economy, 2001)

\begin{tabular}{llccccc}
\hline \multicolumn{1}{c}{ Város } & $\begin{array}{c}\text { IKT } \\
\text { cégek } \\
\text { száma }\end{array}$ & $\begin{array}{c}\text { Média- } \\
\text { gazdaság } \\
\text { cégeinek } \\
\text { száma }\end{array}$ & Együtt & $\begin{array}{c}\text { Azinfo- } \\
\text { kógek aránya ációs } \\
\text { ósszes céghez viszo- } \\
\text { nyítva a városban }\end{array}$ & $\begin{array}{c}\text { A város részesedése } \\
\text { a megyében talál- } \\
\text { ható infokommu- } \\
\text { nikációs cégekból }\end{array}$ \\
\hline 1 & Debrecen & 388 & 257 & 645 & $6,59 \%$ & $88,24 \%$ \\
2 & Pécs & 341 & 298 & 639 & $7,15 \%$ & $81,92 \%$ \\
3 & Szeged & 387 & 231 & 618 & $7,50 \%$ & $84,54 \%$ \\
4 & Miskolc & 295 & 210 & 505 & $6,31 \%$ & $63,28 \%$ \\
5 & Székesfehérvár & 295 & 140 & 435 & $7,60 \%$ & $58,86 \%$ \\
6 & Györ & 271 & 163 & 434 & $6,48 \%$ & $64,39 \%$ \\
7 & Nyíregyháza & 242 & 140 & 382 & $6,70 \%$ & $83,96 \%$ \\
8 & Kecskemét & 197 & 175 & 372 & $7,11 \%$ & $50,13 \%$ \\
9 & Szolnok & 146 & 110 & 256 & $7,05 \%$ & $63,21 \%$ \\
10 & Szombathely & 134 & 98 & 232 & $6,75 \%$ & $73,65 \%$ \\
11 & Veszprém & 105 & 99 & 204 & $6,88 \%$ & $51,26 \%$ \\
12 & Kaposvár & 100 & 91 & 191 & $6,40 \%$ & $52,04 \%$ \\
13 & Békéscsaba & 82 & 105 & 187 & $7,37 \%$ & $54,52 \%$ \\
14 & Eger & 99 & 77 & 176 & $6,81 \%$ & $52,07 \%$ \\
15 & Tatabánya & 88 & 67 & 155 & $5,65 \%$ & $33,70 \%$ \\
16 & Zalaegerszeg & 79 & 67 & 146 & $4,95 \%$ & $42,44 \%$ \\
17 & Dunaújváros & 86 & 51 & 137 & $5,92 \%$ & $18,54 \%$ \\
18 & Sopron & 58 & 60 & 118 & $5,11 \%$ & $17,51 \%$ \\
19 & Szekszárd & 71 & 45 & 116 & $5,83 \%$ & $46,22 \%$ \\
20 & Salgótarján & 50 & 47 & 97 & $7,18 \%$ & $47,09 \%$ \\
21 & Nagykanizsa & 49 & 25 & 74 & $4,53 \%$ & $21,51 \%$ \\
22 & Hódmezövásárh. & 28 & 16 & 44 & $3,83 \%$ & $6,02 \%$ \\
\hline
\end{tabular}

Forrás: Cég-Kód-Tár alapján saját számítás. 
A megyei jogú városokra jellemzó, hogy a megye IKT cégeiből való nagyobb részesedésük nem egyenletesen oszlik el az egyes szakágazatok között. A feldolgozóiparból átlagosan 25 százalékkal kevesebb, a termékhez nem kapcsolódó IKT szolgáltatásokból 5 százalékkal nagyobb mértékben részesednek (8. táblázat). A megyei jogú városok tehát a erőteljesebben specializálódnak a szolgáltatási tevékenységekre, míg a többi telepúlésen alacsonyabb koncentrációban jelen lévö IKT szektor a feldolgozóipar felé tolódik el.

\section{TÁBLÁZAT}

A megyei jogú városok részesedése a megye IKT szektorából, az IKT alágazataiból, illetve a két érték eltéréseinek kimutatása

(The Share of County Rank Towns in the Counties' ICT Sector and the Subbranches of ICT and the Demonstration of the Differences between the Two Values)

\begin{tabular}{|c|c|c|c|c|c|c|c|}
\hline \multirow[b]{2}{*}{ Város } & \multicolumn{3}{|c|}{$\begin{array}{c}\text { Részesedés az adott szakágazat } \\
\text { megyei összes cégszámából }\end{array}$} & \multicolumn{4}{|c|}{$\begin{array}{c}\text { Eltérés a megye IKT cégeiből } \\
\text { való részesedéstől } \\
\text { szakágazatonként } \\
\end{array}$} \\
\hline & $\begin{array}{l}\text { IKT } \\
\text { feldol- } \\
\text { gozó- } \\
\text { ipar }\end{array}$ & $\begin{array}{c}\text { IKT } \\
\text { termékhez } \\
\text { kapcsoló- } \\
\text { dó szol- } \\
\text { gáltatás }\end{array}$ & $\begin{array}{c}\text { Termékhez } \\
\text { nem kap- } \\
\text { csolódó } \\
\text { IKT szolgál- } \\
\text { tatás }\end{array}$ & $\begin{array}{c}\text { IKT } \\
\text { szektor } \\
\text { összesen }\end{array}$ & $\begin{array}{l}\text { IKT } \\
\text { feldol- } \\
\text { gozó- } \\
\text { ipar }\end{array}$ & $\begin{array}{c}\text { IKT } \\
\text { termékhez } \\
\text { kapcsolódó } \\
\text { szolgáltatás }\end{array}$ & $\begin{array}{c}\text { Termékhez } \\
\text { nem kap- } \\
\text { csolódó } \\
\text { IKT szol- } \\
\text { gáltatás }\end{array}$ \\
\hline Pécs & $65,22 \%$ & $75,61 \%$ & $87,23 \%$ & $83,58 \%$ & $-21,97 \%$ & b $-9,53 \%$ & $4,37 \%$ \\
\hline Kecskemét & $41,67 \%$ & $33,33 \%$ & $52,72 \%$ & $48,64 \%$ & $-14,34 \%$ & $-31,47 \%$ & $8,39 \%$ \\
\hline Békéscsaba & $50,00 \%$ & $46,15 \%$ & $52,63 \%$ & $51,25 \%$ & $-2,44 \%$ & b $\quad-9,94 \%$ & $2,70 \%$ \\
\hline Miskolc & $57,14 \%$ & $71,43 \%$ & $64,36 \%$ & $64,13 \%$ & $-10,90 \%$ & b $11,38 \%$ & $0,37 \%$ \\
\hline Hódmezővásárhely & $2,70 \%$ & $5,62 \%$ & $6,88 \%$ & $6,28 \%$ & $-56,95 \%$ & $-10,51 \%$ & $9,51 \%$ \\
\hline Szeged & $72,97 \%$ & $76,40 \%$ & $91,25 \%$ & $86,77 \%$ & $-15,90 \%$ & $-11,95 \%$ & $5,16 \%$ \\
\hline Dunaújváros & $7,59 \%$ & $8,33 \%$ & $22,32 \%$ & $18,70 \%$ & $-59,38 \%$ & $-55,43 \%$ & $19,38 \%$ \\
\hline Székesfehérvár & $67,09 \%$ & $72,22 \%$ & $62,61 \%$ & $64,13 \%$ & $4,61 \%$ & b $12,62 \%$ & $-2,37 \%$ \\
\hline Győr & $55,10 \%$ & $57,35 \%$ & $72,95 \%$ & $68,09 \%$ & $-19,08 \%$ & b $-15,77 \%$ & $7,14 \%$ \\
\hline Sopron & $4,08 \%$ & $20,59 \%$ & $14,95 \%$ & $14,57 \%$ & $-71,99 \%$ & b $41,28 \%$ & $2,56 \%$ \\
\hline Debrecen & $79,41 \%$ & $91,67 \%$ & $90,80 \%$ & $90,02 \%$ & $-11,79 \%$ & $1,83 \%$ & $0,86 \%$ \\
\hline Eger & $32,43 \%$ & $43,75 \%$ & $54,42 \%$ & $49,50 \%$ & $-34,48 \%$ & b $-11,62 \%$ & $9,94 \%$ \\
\hline Tatabánya & $25,58 \%$ & $50,00 \%$ & $29,58 \%$ & $30,99 \%$ & $-17,44 \%$ & $61,36 \%$ & $-4,55 \%$ \\
\hline Salgótarján & $30,00 \%$ & $50,00 \%$ & $54,67 \%$ & $49,50 \%$ & $-39,40 \%$ & $1,00 \%$ & $10,43 \%$ \\
\hline Kaposvár & $45,45 \%$ & $35,71 \%$ & $52,29 \%$ & $49,26 \%$ & $-7,73 \%$ & $-27,50 \%$ & $6,14 \%$ \\
\hline Nyíregyháza & $80,77 \%$ & $71,05 \%$ & $91,94 \%$ & $88,00 \%$ & $-8,22 \%$ & $-19,26 \%$ & $4,48 \%$ \\
\hline Szolnok & $34,09 \%$ & $59,09 \%$ & $72,84 \%$ & $64,04 \%$ & $-46,76 \%$ & $\quad-7,72 \%$ & $13,75 \%$ \\
\hline Szekszárd & $27,78 \%$ & $50,00 \%$ & $46,46 \%$ & $44,65 \%$ & $-37,79 \%$ & $=11,97 \%$ & $4,04 \%$ \\
\hline Szombathely & $76,92 \%$ & $72,73 \%$ & $73,13 \%$ & $73,63 \%$ & $4,48 \%$ & $-1,22 \%$ & $-0,67 \%$ \\
\hline Veszprém & $24,24 \%$ & $78,57 \%$ & $54,78 \%$ & $51,47 \%$ & $-52,90 \%$ & $52,65 \%$ & $6,42 \%$ \\
\hline Nagykanizsa & $34,62 \%$ & $38,89 \%$ & $24,09 \%$ & $27,07 \%$ & $27,86 \%$ & $43,65 \%$ & $-11,02 \%$ \\
\hline \multirow[t]{2}{*}{ Zalaegerszeg } & $15,38 \%$ & $27,78 \%$ & $51,09 \%$ & $43,65 \%$ & $-64,75 \%$ & $-36,36 \%$ & $17,07 \%$ \\
\hline & & & & Atlag: & $-25,33 \%$ & $-0,48 \%$ & $5,19 \%$ \\
\hline
\end{tabular}

Forrás: Cég-Kód-Tár alapján saját szerkesztés. 
A Lengyel Imre és Rechnitzer János (2000) által készített 1998-as évre vonatkozó statikus és az 1990-1998. évekre vonatkozó, dinamikát jelzö versenyképességi rangsorok a megyei jogú városok gazdasági potenciálját és annak változásait mutatják be. Ehhez tettük hozzá az IKT szektor és a médiagazdaság három jellemző adatsorát (9. táblázat).

\section{TÁBLÁZAT}

A megyei jogú városok rangsorai különbözö ismérvek alapján, 2001 (The Orders of the County Rank Towns by Different Criterions, 2001)

\begin{tabular}{lccccc}
\hline \multicolumn{1}{c}{ Város } & (A) & (B) & (C) & (D) & (E) \\
\hline Debrecen & 5 & 13 & 1 & 1 & 5 \\
Szeged & 18 & 8 & 2 & 3 & 1 \\
Pécs & 7 & 15 & 3 & 4 & 2 \\
Székesfehérvár & 1 & 2 & 4 & 7 & 6 \\
Miskolc & 17 & 17 & 5 & 8 & 3 \\
Györ & 2 & 1 & 6 & 6 & 13 \\
Nyíregyháza & 10 & 20 & 7 & 2 & 7 \\
Kecskemét & 15 & 14 & 8 & 15 & 17 \\
Szolnok & 13 & 9 & 9 & 9 & 4 \\
Szombathely & 3 & 5 & 10 & 5 & 10 \\
Veszprém & 9 & 3 & 11 & 10 & 11 \\
Kaposvár & 19 & 18 & 12 & 14 & 20 \\
Eger & 8 & 10 & 13 & 13 & 21 \\
Tatabánya & 12 & 21 & 14 & 18 & 9 \\
Dunaújváros & 4 & 4 & 15 & 20 & 15 \\
Békéscsaba & 21 & 16 & 16 & 11 & 8 \\
Zalaegerszeg & 11 & 7 & 17 & 17 & 12 \\
Szekszárd & 20 & 6 & 18 & 16 & 18 \\
Sopron & 6 & 12 & 19 & 21 & 14 \\
Salgótarján & 16 & 22 & 20 & 12 & 16 \\
Nagykanizsa & 14 & 11 & 21 & 19 & 19 \\
Hódmezövásárhely & 22 & 19 & 22 & 22 & 22 \\
\hline
\end{tabular}

Jelmagyarázat:

(A) A megyei jogú városok versenyképességi rangsora, dinamikus, 1990/98. (LengyelRechnitzer 2000)

(B) A megyei jogú városok versenyképességi rangsora, statikus. 1998. (Lengyel-Rechnitzer 2000)

(C) IKT szektorba tartozó cégek száma, 2001.

(D) A megyei jogú város részesedése a megye IKT szektorba tartozó cégeinek számából, 2001.

(E) IKT és médiagazdaság cégeinek száma 10000 lakosra, 2001.

Forrás: Lengyel-Rechnitzer 2000; Cég-Kód-Tár alapján saját szerkesztés.

Az öt rangsor kapcsolatának szorosságát Spearman-féle rangkorrelációs együtthatóval tesztelve kiderült, hogy akár a statikus, akár a dinamikus adatsorral összevetve az infokommunikációs jellemzőket, azok teljesen függetlenek egymástól, csak az 
IKT szektor cégeinek száma és a dinamikus adatsor között létezik gyenge kapcsolat (10. táblázat). A Spearman-féle rangkorreláció azért alkalmas ebben az esetben, mert az öt rangsor közötti kapcsolat szorosságát eleve csak páronként volt érdemes összevetni, mivel a bennük felállított sorrendek láthatóan erősen eltértek egymástól.

A másodikként feltett hipotézis bizonyítására tett kisérlet tehát sikertelen, ennek okai a következők:

1) Módszertani problémák: Az IKT szektor és a médiagazdaság dinamikusan fejlődő iparágak, ezért a három éves időkülönbség már jelentős eltéréseket okozhat. A két megyei jogú várossal rendelkező megyékben kevésbé valószínü, hogy az egyik városba koncentrálódnak a cégek (kivéve Hódmezővásárhely), ezért mindkettő hátrébb sorolódik a rangsorokban.

2) Az öt hagyományos megyei város (Györ, Pécs, Szeged, Debrecen, Miskolc), valamint Székesfehérvár és Kecskemét kitüntetett szerepe az IKT szektorban és a médiagazdaságban. Ez a tény arra enged következtetni, hogy az infokommunikációs ágazatok telepítési tényezöi (valószínủleg) eltérnek a gazdaság más ágazataitól: feltünỏ a népességi centrumok, közigazgatási és oktatási központok, a kiépült infrastruktúrával rendelkező nagyvárosok IKT-és médiagazdasági cégekből való nagy részaránya, viszont úgy tünik, hogy ezek a szektorok kevésbé igénylik az autópálya meglétét.

$\mathrm{Az}$ infokommunikációs ágazat gazdasági fejlődésben, technológiai váltásban betöltött szerepe, a foglalkoztatásban meglévő súlya arra predesztinálja, hogy amint megfelelő mennyiségü adat elérhetővé válik, mint jellemzőt be kell építeni a közgazdasági és területi elemzésekbe. Magyarországnak a tudástársadalom felé haladva azt próbálja megmutatni, hogy az új technológiák területén vannak versenyképességet növelö, értékesíthető (szellemi és infrastrukturális) tartalékai.

\section{TÁBLÁZAT}

A kapcsolat erössége a különböző rangsorok között

(Spearman-féle rangkorrelációs együttható értéke)

(The Strengths of Correlation between the Different Order of Ranks -

The Value of the Spearman Rank-correlation Coefficient)

\begin{tabular}{cccccc}
\hline & A & B & C & D & E \\
\hline A & - & 0,5483 & 0,3890 & 0,3066 & 0,2287 \\
B & 0,5483 & - & 0,2027 & 0,1169 & 0,0593 \\
C & 0,3890 & 0,2027 & - & 0,8498 & 0,7357 \\
D & 0,3066 & 0,1169 & 0,8498 & - & 0,7244 \\
E & 0,2287 & 0,0593 & 0,7357 & 0,7244 & - \\
\hline
\end{tabular}

Jelmagyarázat:

(A) A megyei jogú városok versenyképességi rangsora, dinamikus, 1990/98. (Lengyel-Rechnitzer 2000)

(B) A megyei jogú városok versenyképességi rangsora, statikus, 1998. (Lengyel-Rechnitzer 2000)

(C) IKT szektorba tartozó cégek száma, 2001.

(D) A megyei jogú város részesedése a megye IKT szektorba tartozó cégeinek számából, 2001.

(E) IKT és médiagazdaság cégeinek száma 10000 lakosra, 2001.

Forrás: Saját szerkesztés a 9. táblázat adatai alapján. 


\section{A tanulmány megállapításai, a továbblépés lehetöségei}

Az IKT szektor és a médiagazdaság erőteljesen fejlödik, jelenleg 9200 vállalkozás a nemzetgazdasági összlétszám több mint öt százalékát foglalkoztatja.

$\mathrm{Az}$ infokommunikációs ágazatok az ország területén nagyon egyenlötlenül helyezkednek el: Budapesten összpontosul az IKT szektor cégeinek 56 százaléka és a médiagazdaság 63 százaléka.

Az IKT szektor és a médiagazdaság vállalkozásai városonként együtt, egymás közelében jelennek meg, a két ágazat kölcsönhatása nagyon erös.

A megyék IKT szektorára és médiagazdaságára vonatkozó benchmarking elemzés Budapest vezető szerepén túl egyértelmủen Pest, Fejér, Csongrád, Baranya és GyőrMoson-Sopron megye nagyobb súlyát mutatta ki.

A megyei jogú városoknak egy korábbi, a városhálózat versenyképességére vonatkozó kutatással való rangkorrelációs összevetése alapján valószínü, hogy a gazdasági potenciál hagyományos mérỏszámai nem fedik le az infokommunikációs ágazatokat, ezért új adatok, új mutatók bevezetése vált időszerüvé.

A tanulmány elkészítése közben számos kérdés merült fel, amelyeknek megválaszolása újabb kutatásokra ad lehetőséget:

1) Milyen tényezök állnak az IKT szektor és a médiagazdaság szoros együtt mozgása mögött?

2) Hogyan változtak (keletkeztek) az infokommunikációs ágazatok az elmúlt években, lehetséges-e prognózist készíteni?

3) Összehasonlítható-e a rendelkezésre álló magyar területi adatbázis más (európai uniós vagy közép-európai) országokéval, milyen kutatói kapcsolatok szükségesek ehhez?

4) Melyek az IKT szektor telepítési tényezői (esettanulmányok és statisztikai elemzés tükrében)? Hogyan hasznosíthatók az így keletkezett információk az üzleti szférában?

5) A magyar területfejlesztési politika hogyan hat az infokommunikációs ágazatok térszerkezetére? Szükséges-e az irányváltás?

6) Milyen összefủggés van az IKT szektor és a médiagazdaság innovációinak területi terjedése és a puha gazdasági tényezők (szellemi potenciál, politika, felsőoktatási és kutatói intézmények jelenléte) között?

A tanulmány befejezéseképpen elmondhatjuk, hogy elemzésünk elérte célját, a jelenleg elérhetô statisztikai adatok segítségével bemutatta az infokommunikációs ágazatoknak a városhálózatban betöltött gazdasági szerepét, és az ágazatok térbeli kiterjedésére, egyenlötlenségeire vonatkozó legalapvetőbb megállapításokat, illetve a tapasztalatok alapján felvázolta az infokommunikációs ágazatokra vonatkozó térkutatás további lehetséges irányait. 


\section{Jegyzetek}

${ }^{1}$ World Development Report. (1999) Knowledge for Development. The World Bank 1998/99. Oxford University Press, New York.

2 1997-ben indult az információs társadalom statisztikai projekt a KSH-ban, ahol célul tủzték ki az új adatok gyüjtését és a nemzetközi módszertan tanulmányozását. Magyarországon a témakörben a számítástechnikai ágazat szolgáltatóinak és szolgáltatásainak felmérése, a kábeltelevíziós vállalkozások tevékenységének elemzése, a központi államigazgatás informatikai eszközei és információs tevékenysége, az internetes szolgáltatások, az internetszolgáltatók forgalmi adatai, valamint az IKT szektor felmérése történt meg ( $K S H$ 2001.)

3 A KHVM rendszeresen megjelenö évkönyve viszont nagyrészt megyei bontásban, illetve szolgáltatónként írja le a hazai információs gazdaság infrastruktúrájának és a kihasználtságának jellemzöit.

${ }^{4}$ A Kendall-féle konkordancia mutató az ismérvek (jelen esetben a két ágazathoz tartozó cégek száma az adott megyében) egyes rangszámösszegeinek az átlagtól vett eltérésének a négyzetösszegét viszonyítja annak lehetséges maximumához. A mutató 1 (teljes sorrendi azonosság minden ismérv esetén) és 0 (teljesen különbözö sorrendek esetén) közötti értéket vehet fel. A Spearman-féle rangkorrelációs együtthatóval szembeni elönye, hogy kettoonél több ismérv esetén is használható a rangsorok egyezöségének vizsgálatára.

\section{Irodalom}

Dohse, D. (1998) Wissensdiffusion und regionales Wirtschaftswachstum. Seminarberichte 40. Gesellschaft für Regionalforschung. 19-35. o.

Döry T.-Rechnitzer J. (2000) Regionális innovációs stratégiák. Oktatási Minisztérium, Budapest.

Glatz F. (szerk.) (2000) Az információs társadalom. Magyarország az ezredfordulón Stratégiai Kutatások IV. MTA, Budapest.

Kerékgyártó Gy.né-Mundruczó Gy. (1999) Statiszrikai módszerek a gazdasági elemzésben. Aula Kiadó Kft., Budapest. 63-67. o.

KSH (2000) A gazdaság növekedését elösegitổ húzóágazatok - nemzetközi összehasonlitásban. Központi Statisztikai Hivatal, Budapest.

KSH (2001) Az információs és kommunikációs technológiai szektor Magyarországon, 1995-1999. Központi Statisztikai Hivatal, Budapest. 6. o.; 56-59. o.

Lengyel I.-Rechnitzer J. (2000) A városok versenyképességéröl, - Horváth Gy.-Rechnitzer J. (szerk.) Magyarország területi szerkezete és folyamatai az ezredfordulón. MTA Regionális Kutatások Központja, Pécs. 130-152. o.

Schönert, M.-Willms, W. (2000) Medienwirtschaft in deutschen Großstädten. BAW Institut für Wirtschaftsforschung $\mathrm{GmbH}$.

Nemzeti Információs Társadalom Stratégia (2001) Miniszterelnöki Hivatal Informatikai Kormánybiztossága, Budapest.

Palkovits I. (2000) Szempontok a területi versenyképesség értelmezéséhez. - Tér és Társadalom. 2-3. 119-128. o.

Polányi, M. (1958) Personal Knowledge: Towards a Post-Critical Philosophy. Chicago.

Varga, A. (1998) Universify Research and Regional Innovation. A Spatial Econometric Analysis of Academic Technology Transfers. Kluwer Academic Publishers, Boston, Dordrech!, London.

Világ, gazdaság '99: Adatok, tények, tendenciák (1998) Világgazdaság évkönyv. Zöld Újság Rt., Budapest. 